\title{
CURRENT CONCEPTS AND CHARACTERISTICS OF SELF-HARMING BEHAVIOUR
}

\author{
Sergey Igumnov ${ }^{1,3}$, Sergey Davidovsky ${ }^{2}$, Robert Iskandarov ${ }^{3}$, Olga Iskandarova ${ }^{4}$ \\ ${ }^{I}$ Belarusian State Pedagogical University branch M. Tank, Minsk, Belarus, \\ ${ }^{2}$ Belarusian State Medical Academy for Postgraduate Education, Minsk, Belarus, \\ ${ }^{3}$ National Research Centre for Addictions, Moscow, Russia, \\ ${ }^{4}$ Moscow Aviation Institute (National Research University), Moscow, Russia
}

Keywords: Suicidal and self-harming behavior, suicidal ideation, the International Classification of Diseases 10th revision, borderline personality disorder, alcohol, psychoactive substances, COVID-19 pandemic.

\begin{abstract}
Summary
Several biological risk factors for suicidal and self-harming behaviour have now been identified. The differences relate to changes in key neurotransmitter systems (serotonergic, polyamine stress response, glutamatergic and GABAergic systems), inflammatory response, astroglial dysfunction, neuronal plasticity factor, confirming the need to differentiate between those motivated to commit suicide and those prone to non-suicidal self-harming behaviour from total suicide attempts.

Non-suicidal self-injurious behaviour (self-injurious thoughts and behaviours or non-suicidal self-injury (NSSI)) is defined as repeated, deliberate, direct damage to the body without suicidal intent, which is not socially acceptable. An integrated theoretical model of NSSI development and support suggests that this type of behaviour functions as a method of regulating emotional experience and social interaction when a stressful event occurs. NSSI is currently included in Section 3 of the DSM-5 (Diagnostic and Statistical Manual of Mental Disorders, Fifth Edition) and is listed as a condition recommended for further study. The American Diagnostic and Statistical Manual of Mental Disorders, 4th Revision (DSM-IV-TR) and the International Classification of Diseases, 10th Revision (ICD-10) code NSSI as a symptom of borderline personality disorder.
\end{abstract}

Recent studies have shown that $59.6 \%$ of individuals with NSSI show signs of substance abuse.

There are concerns that rates of suicide and suicidal be- haviour may increase during and after the COVID-19 pandemic.

\section{Introduction}

Non-suicidal self-injury (NSSI) is defined as repeated, deliberate, direct damage to the body without suicidal intent, which is not socially acceptable [24;61], and is done to reduce psychological discomfort. In the last decade, there has been an increased interest in non-suicidal injuries worldwide $[8 ; 7]$.

NSSI manifestations most commonly occur in early adolescence, between the ages of 12 and 14 [58; 55]. Most researchers note that suicidal behaviour in children under 13 years of age is rare [13], with suicidal activity rising sharply from 14-15 years of age, reaching a maximum by $16-19$ years of age $[58 ; 55 ; 1]$. A.G. Ambrumova, having investigated 770 children, teenagers and young people with suicidal behaviour found, that in pre-pubertal age (up to 13 years) 14.4 $\%$ attempted suicide, in pubertal age (13-16 years) - $51.3 \%$, in post-pubertal age (17-18 years) - $33.8 \%$ [1]. The main distinction between self-harming behaviour and suicide attempts is the absence of a conscious intention to take one's own life. It should be borne in mind that some non-suicidal self-harm behaviours, particularly in adolescence, can lead to death because of ignorance or incorrect "dose calculation", as the authors of the article have encountered in their clinical practice.

It should also be remembered that these two forms of self-harm can overlap: individuals who attempt suicide may also exhibit non-suicidal self-harming behaviour and vice versa. In real clinical situations, the presence of suicidal intentions is often very difficult to assess, even for professionals with extensive practice experience, which constitutes a serious barrier to the study of this problem. Therefore, 
although self-harming behaviour is a widespread phenomenon, NSSI prevalence data vary considerably between countries. This is also influenced by specific methodological approaches and, in particular, factors such as the type of behaviour classified as NSSI, as well as the NSSI estimation method, the demographic characteristics of the sample, etc. High prevalence rates are reported among adolescents in residential treatment, e.g. $30 \%$ to $82.4 \%$ [21; 59], and a moderate prevalence is reported in the general population. In a review of 53 studies published between 2005 and 2011 on NSSI in adolescents, an average lifetime prevalence of $18 \%$ was reported [54]. Among university students, the percentage is as high as $38.9 \%$ and $4-23 \%$ among adults $[30,80,64,12]$. Current prevalence figures are approximately $17.2 \%$ among adolescents, $13.4 \%$ among young adults and students, and $5.5 \%$ among adults over 25 years of age. These figures are consistent with a separate review of the prevalence of NSSI in adolescents [54] and a large study of randomly selected adults [46]. NSSI is thought to be much more common in women than in men. For example, according to data for the Minsk region for 2015-2019, girls accounted for $85 \%$ of all self-harm cases among children and adolescents.

Suicide deaths between the ages of 15-29 account for $8.5 \%$ of all deaths, being the second leading cause of death after road traffic accidents worldwide [82]. It should be noted that adolescence and the period of early adulthood (20-29 years) are characterised by dramatic changes in the body and are characterised by heightened arousal, sudden changes in mood and experiences, which causes an increased reactivity of the adolescent's natural stress response to social stimuli, thus creating a uniquely vulnerable time frame for the manifestation of suicidal behaviour. Changes in the brain's neural networks occur during this period, allowing for more complex social comparisons and a more sustained sense of self-esteem, which is highly dependent on perceived peer assessments [16; 33]. Research in developmental neurobiology suggests that adolescents during puberty produce more differentiated responses to environmental stimuli that allow them to build their self-esteem from the social experiences they receive, but that there is no mature ability to regulate their emotions or suppress impulsive responses [72]. The development of object feelings has not yet occurred, which prevents them from forming stable emotional relationships with their immediate environment. Increased reactivity due to adolescence increases the intensity of physiological responses to stressors [74] and prefrontal brain activation during social assessment [72] and thus increases the difficulties associated with evaluating social events [74]. This appears to be the cause of a disruption in the biological responses to acute stress, which may underlie acute sui- cidal crises in adolescents with self-harming behaviour.

One of the types of self-harming behaviour in adolescents is the use of psychoactive substances [2]. Substance use significantly increases the risk of NSSI. At the same time, among adolescents with NSSI the percentage of substance use was 4 times higher than the population [52]. Data are given that up to half of suicide attempts were committed by persons with drug disorders, and $22 \%$ were committed in alcohol intoxication [11]. It was found that about $47 \%$ of persons with NSSI use psychoactive substances, while the proportion of alcohol and drug users without PPS was $4.4 \%$ [34]. An Oxford study found that $59.6 \%$ of those with NSSI had a substance use disorder [75] Comorbidity of NSSI with different types of substance use was established: $12.6 \%$ used marijuana, 29.5\% used alcohol [60].

A recent study in our country found that the highest percentage of substance use of all types of psychoactive substances (alcohol, tobacco, and drugs) is in the group of adolescents with high risk of suicidal behaviour: 56 per cent reported using alcohol, 20.7 per cent reported using tobacco and 12.5 per cent reported trying drugs. Adolescents at risk of self-harming behaviour use tobacco (24.6\%), alcohol (49\%) and drugs $(9.9 \%)$. In the group of adolescents with selfharming behaviour, $49 \%$ indicated that they use alcohol, $25 \%$ use tobacco and $10 \%$ use drugs. The normative behaviour group of teenagers revealed the following results: only 13 per cent reported using alcohol, 3 per cent reported using tobacco, and 0.5 per cent reported using drugs [3].

The aim: Overview of contemporary neurobiological, clinical, and psychosocial concepts explaining the phenomenon of self-harming behaviour.

\section{Self-harming behaviour against the background of a COVID-19 pandemic}

The COVID-19 coronavirus pandemic has caused an unprecedented public health crisis. There are concerns about the impact of the pandemic on public mental health [35]. This can be realized both through the immediate impact of infection and restrictive measures resulting in social isolation and disruption of services and health care facilities, and through increased violence in families during the lockdown. Physical distancing measures have already led to a significant increase in unemployment, a drop in GDP in most countries and the threat of economic recession. The likelihood that suicide and self-harm rates may increase during and after a pandemic is very high $[32 ; 67]$.

Time series modelling has shown that the 1918-20 Spanish influenza pandemic, which caused more than 20 million deaths worldwide, led to a moderate increase in suicide rates in the USA [40]. In addition, there is evidence that suicide rates briefly increased in Hong Kong during the 2003 SARS 


\section{8}

epidemic among people over the age of 65 , predominantly those with somatic pathologies and chemical dependency [17].

However, the current context is very different from that of previous epidemics and pandemics. The 2003 SARS epidemic was confined to a relatively small number of countries. In addition, in the 100 years since the influenza pandemic of 1918-20, global and national health systems have improved dramatically, travel and the speed of information (and misinformation) have multiplied, antibiotics to treat secondary infections have emerged and national economies have become more interdependent. The availability of the Internet and technological advances have made it much easier for people to communicate. At the same time, access to remote technologies that facilitate online clinical assessment and treatment has varied considerably between regions of the world.

Key issues related to suicide prevention during the pandemic include uncertainty in assessment and support for people with suicidal thoughts and behaviour as people who have attempted suicide during the lockdown may avoid clinics for fear of exposure to COVID-19 and traumatic experiences or may not want to be a burden on health services during this period. The growing economic crisis [18], increased alcohol sales and the rise in domestic violence [10] are significant factors in increased suicide and self-harming behaviour.

For example, University College London conducted a large longitudinal study of the psychological and social experiences of more than 50000 adults in the UK during the pandemic. Out of a total sample of 55 481, those who had reported abuse, self-harm and thoughts of suicide or self-harm on at least one occasion were included $(\mathrm{n}=44$ 775). Overall, 4121 participants surveyed (9\%) reported experiencing psychological or physical abuse, 7984 participants $(18 \%)$ reported experiencing suicidal or self-harming thoughts in the first month of isolation and 2174 participants (5\%) reported harming themselves at least once since the UK began isolation. Around $50 \%$ of participants experiencing psychological or physical violence had experienced suicidal or self-harming thoughts and $25 \%$ had engaged in self-harm in the previous week [38].

\section{The main forms of self-harming behaviour}

Forms of NSSI include behaviours such as self-cutting, intentional burns, scratches and blows [55; 46; 80]. It is now believed that most people who commit NSSI use more than one method [80], with traumatic impacts on the arms, legs, wrists and abdomen [46; 82]. Self-harm with sharp objects was considered to be the most common method (over 70\%), followed by head blows, scratches, blows and burns [22; 24]. According to data for Minsk city from 2007-2014, self-harm methods such as self-poisoning and self-harming (at least
$60 \%$ of all self-harm cases, predominantly aged $20-39$ years) were predominant among self-harm methods [25]. According to data for the Minsk region for 2015-2019, the following methods of self-harm were observed: self-harming - $44.5 \%$, poisoning $-38.5 \%$, hanging $-11.4 \%$, falling from a height - $3 \%$, drowning - $0.4 \%, 2.2 \%$ were rarely used methods (gunshot wound, throwing under a train, self-immolation, etc.).

Psychopathological, psychological and neurobiological factors underlying self-harming behaviour

NSSI is common among adolescents and adults associated with significant psychiatric disorders, including PTSD [15], depressive disorders [20], obsessive-compulsive disorder [15], anxiety disorder [20], borderline personality disorder (hereafter-PHD) [61, 47] and eating disorders [36].

Some of the earliest attempts to define the syndrome were made as early as the 1960s by Graff and Mallin, but they failed due to the inclusion of suicide attempts in the definitions of suicidal behaviour [28; 63; 65]. In 1984, Kahan and Pattison [44] differentiated suicidal behaviour from suicide and proposed a separate diagnostic disorder, deliberate selfharm syndrome. Later, Favazza and Rosenthal [25] suggested that habitual and repetitive self-harming behaviour could be regarded as an impulse control disorder. In the early 2000s, Muehlenkamp proposed that NSSI should be considered a separate diagnostic disorder [56]. Subsequently, Wilkinson and Goodyer [81] felt that giving NSSI its own diagnostic category would improve the quality of diagnosis and increase research on etiology, treatment and outcome. Given the high prevalence of self-harming behaviours among clinical samples and in the general adolescent population $[61 ; 7 ; 13]$, the working group on mood disorders in preparing the Diagnostic and Statistical Manual of Mental Disorders Revision 5 (DSM-5) proposed that NSSI be included as a separate diagnostic disorder [71]. The criteria for this disorder have been subject to repeated revisions, due to an incomplete set of proposed criteria, inadequate study sample sizes and inter-rater reliability [66].

NSSI is now included in section 3 of the DSM-5 and categorised as a condition recommended for further study, and the following criteria must be met:

A. The individual has intentionally self-harmed on at least 5 days in the past year without attempting to commit suicide.

B. The individual commits self-harm for one or more of the following reasons: inflicts self-harm expecting to obtain relief from negative emotions; to resolve intrapersonal conflict; trying to achieve a positive emotional state.

C. Self-harming act should (and/or) precede: negative thoughts or feelings $(\mathrm{Cla})$, conflicts with others $(\mathrm{C} 1 \mathrm{~b})$, concern about behaviour that is difficult to control $(\mathrm{C} 2)$, recurrent thoughts about self-harming behaviour (C3). 
D. The act committed is socially unacceptable.

E. Self-harming behaviour or its consequences cause clinically significant destructive stress.

F. The act is unrelated to a psychotic episode, delirium, intoxication or withdrawal syndrome and cannot be the cause of another illness.

Additionally, 2 subtypes of unspecified NSSI are distinguished:

Type 1 (sub-threshold): refers to cases with less than 5 times the frequency of self-harm in the past year;

Type 2 (intent uncertain): cases in which the self-harm was accompanied by a desire to escape unpleasant feelings or to resolve interpersonal difficulties, as well as a desire to commit suicide.

In earlier classification systems (DSM-IV-TR and ICD10), NSSI disorder is coded as a symptom of PDP. All types of auto-aggressive behaviour in ICD-10 are coded according to the nature of the lesion in headings $\mathrm{X}$ and $\mathrm{Y}$. However, the manual states that "this class, which was an additional class in previous revisions of ICD, allows the classification of incidents, conditions and circumstances as the cause of injury, poisoning and other adverse effects. Where a code from this class is used, it is understood that it should be applied in addition to a code from another class indicating the nature of the condition".

The NSSI may occur in individuals who do not receive a diagnosis of PDP, and not everyone who receives a diagnosis of PDP exhibits self-harm-related behaviour [37]. The distinction between the NSSI group and the PDP-group suggests defining NSSI as a syndrome in its own right $[77 ; 70]$. The introduction of NSSI disorder recognises the importance of differentiating NSSI from suicide attempt. Although both suicide attempts and NSSI correspond to self-harm behaviours, there are important clinical differences between these behaviours, both in aetiology and in the functions and methods performed. The American Psychiatric Association's study of NSSI disorder showed a high percentage of those who were self-harming and met the criteria proposed by the DSM-5 $[27 ; 29]$. In combined samples of inpatients and intensive outpatients, $85.5 \%$ met criterion A [79]. When evaluating criterion $\mathrm{B}$, a high approval rate was found in a clinical sample of adolescents and adults $[37 ; 79 ; 83]$, as well as in general adult samples $[37 ; 29]$.

A study of the psychological reasons behind NSSI behaviour in a German sample found that 56.8 per cent of a German sample of inpatients used NSSI "to stop bad feelings" [43]. According to B. Almazov (1981) [9], who examined a group of adolescents aged 14-18 who had deliberately cut themselves, it was found that only $4 \%$ of those examined had suicidal thoughts at the time of self-harm, $30 \%$ committed self-harm as a result of an argument with peers, $20 \%$ as a "blood brotherhood" rite and $20 \%$ as a display, bravado before peers.

NSSI is now thought to be a transient phenomenon, with a large longitudinal study showing a decline in this type of behaviour at a young age [53]. An integrated theoretical model of NSSI development and support [61] suggests that this type of behaviour functions as a method of regulating both emotional experience and social situations when a stressful event occurs. This model was introduced by M. K. Nock and M. J. Prinstein (2004), known as the Four Factor Model in the English transcription The Four Factor Model (hereinafter FFM) [59]. The FFM model is based on behavioral theory that focuses on antecedent and consequent influences on behaviour. The FFM distinguishes between two dichotomous dimensions of functional processes: interpersonal/social and intrapersonal/automatic contingencies and reinforcement of the positive versus the negative. The four processes proposed by the model include: automatic negative reinforcement when NSSI serves to reduce negative internal states, automatic positive reinforcement when NSSI serves to generate positive feelings, social negative reinforcement when NSSI serves to avoid interpersonal needs, and social positive reinforcement when NSSI serves to attract attention or increase social support [61].

The "self-punishment" function was generally noted by adolescents and adults among clinical samples [43; 14; 48]. For adults, the function of NSSI is more to reduce negative emotions and experiences than to gain social support [12]. It can be said that in adults, self-harming behaviour often serves the function of "restoring a normal emotional state" and provides an opportunity for distraction from a crisis situation.

Different brain morphology and neural activity in patients with NSSI or with PLD compared to healthy controls has also been noted, which may be due to different perceptions of emotional and physical pain. The neurobiological model of NSSI [73] suggests that abnormalities in the serotonergic, dopaminergic and opioid systems as well as in the hypothalamic-pituitary-adrenal (hereafter-HGN) axis result in increased levels of stress susceptibility. Therefore, in the case of stress, the use of NSSI can be interpreted as a method of restoring altered opioid homeostasis. Magnetic resonance therapy studies indicate hyperexcitation of limbic structures (such as the amygdala) [64]. Activation of these structures decreases both after induction of painful stimuli and after imagining an NSSI act [69]. This leads to the assumption that NSSI serves to regulate stress in a strongly activated limbic system.

In terms of neurotransmitter levels, there is ample evi- 
dence of a link between impulsive behaviour and a lack of serotonin. However, NSSI often cannot be described as predominantly impulsive behaviour [45; 39]. Currently, there is little evidence in favor of a supportive mechanism of serotonin deficiency in the formation of NSSI [48], in contrast to the established association between serotonergic dysfunction and an increased risk of violent suicide attempt $[19 ; 23]$, which was confirmed by a study conducted within the framework of the State Research Program "Basic and applied sciences - medicine", which revealed statistically significant differences between groups with violent and nonviolent methods of self-harm in the occurrence of the HTR1 genotype [5].

The same is true for the involvement of dopaminergic neurotransmission in people with NSSI, and studies [48] have found no differences in the levels of serotonin or dopamine metabolites in the cerebrospinal fluid of patients with NSSI. Cortisol and GHN-axis studies in humans and animals with NSSI have shown an altered cortisol response [76; 42]. Researchers have also noted an altered level of endogenous opioids, which may explain the addictive quality of NSSI that has been described in people with severe NSSI [57]. These endogenous opioids may provide an explanation for the phenomenon of hypalgesia or analgesia in patients with recurrent NSSI, which appears to be reversible after discontinuation of NSSI [49]. Interestingly, a recent meta-analysis [51] described adolescent suicide as a failure of systems involved in acute stress responses: autonomic nervous system, HGH axis, inflammatory response, which confirms the integrated theoretical model of NSSI proposed by Nock (2010).

Conducted as part of the research work "To study molecular and genetic predictors of suicidal behaviour in order to develop diagnostic criteria for increased risk of suicide" (State research programme "Fundamental and applied sciences - medicine", state registration No 20161106 of 11.06.2016, Republic of Belarus, with the scientific and methodological assistance of the National Medical Research Centre of Psychiatry and Narcology named after A.P. Serbsky, Ministry of Health of the Republic of Belarus. The study also revealed the presence of socio-psychological, biochemical and genetic factors that allow differentiating between different forms of self-harming behaviour depending on the severity of motivation to commit suicide, which has been outlined in a number of scientific articles [23; 4]. As a result of the current study, it was observed that in the group of individuals with self-harming behaviour, there was an increase in corticotropic releasing factor (hereinafter, CTRH) and a decrease in adrenocorticotropic hormone (hereinafter, $\mathrm{ACTH}$ ) and cortisol compared to controls, as opposed to individuals with a strong motivation to commit suicide. In this group, on the contrary, there was a decrease of CRTH level and simultaneous increase of ACTH and cortisol, which indicated disorganization of the GHN axis. The frequency of the $\mathrm{C}$ allele of the HTR1A gene in males in the group of individuals motivated to commit suicide was significantly higher than the frequency of this allele in males committing various types of self-harm $(p=0.04)$.

Several biological risk factors have now been identified as responsible for suicidal and self-harming behaviour: changes in key neurotransmitter systems (serotoninergic, polyamine stress response, glutamatergic and GABAergic systems), inflammatory response, astroglial dysfunction, neuronal plasticity factor, content of lipoprotein fractions in peripheral blood [22; 78], confirming the need to distinguish suicide-motivated individuals, whose ratio according to WHO is $1: 20$ [82]. To date, three additional diagnoses describing suicidal behaviour have been proposed:

- Suicidal behaviour disorder (in English transcription suicidal behaviour disorder (SBD)) [62], focusing on attempted suicide within the past two years. It is included in section 3 and requires further study [66], as does the NSSI.

- Suicide Crisis Syndrome (hereinafter referred to as SCS) [26] and

- Acute Suicidal Affective Disorder (ASAD) [68], which describe acute suicidal affective disorder, which describe an acute pre-suicidal mental state and are not in DSM-5, as the concept of these disorders was described much later.

The two syndromes listed below overlap symptomatically but are also quite different in that SCS does not involve suicidal ideation, whereas ASAD is based on rapidly increasing suicidal activity $[68 ; 41]$. All this points to the current formation of new concepts and ideas about suicidal or selfharming behaviour, which will allow a more differentiated approach to the description of this complex phenomenon in the future, identifying significant triggers for the formation of motivation to commit suicide and the signs characteristic of non-suicidal self-harming behaviour.

\section{Conclusions}

Thus, the development of new diagnostic criteria provides clarity in understanding the characteristics of self-harming behaviour and will help to effectively identify individuals at risk of suicide.

No conflict of interest

\section{Reference}

1. Ambrumova A.G., Zhezlova L.Ja. Metodicheskie rekomendacii po profilaktike suicide-al'nyh dejstvij v detskom i podrostkovom vozraste [Methodical recommendations for prevention of suicidal actions by children and adolescents]. Moscow, 1978. 
13 p. (In Russ.)

2. Grigoryeva A.A., Bulygina V.G., Afonina YU.S. Vzaimosvyaz' samopovrezhdayushchego povedeniya i upotrebleniya psihoaktivnyh veshchestv podrostkami (obzor literatury) [The relationship between self-harming behavior and substance use in adolescents (literature review)]. Sibirskij vestnik psihiatrii i narkologii /Siberian Herald of Psychiatry and Addictions 2018; 4 (101): 98-104. (In Russ.).

3. Grigoryeva A.A., Gavrichenkova A.A. Upotreblenie podrostkami psihoaktivnyh veshchestv pri raznyh vidah autoagressivnogo povedeniya [Use of psychoactive substances by adolescents in different types of auto-aggressive behaviour]. Psihologiya i pravo / Psychology \& Law 2020; 10 (1): 116-122. (In Russ.) https://doi.org/10.17759/psylaw.2020100110

4. Davidovskij S.V., Ibragimova Zh.A., Goncharik A.V, Kartun., L.V., Leonov N.N., Danilova L.I. et al. Metod klassifikacii dlya prognozirovaniya riska suicida [A Classification method for predicting suicide risk]. Izvestiya Nacional'noj akademii nauk Belarusi. Seriya medicinskih nauk / Proceedings of the National Academy of Sciences of Belarus. Medical Sciences Series 2020; 17 (2): 248-256 (In Russ.).

5. Davidovskij S.V., Ibragimova Zh.A., Goncharik A.V., Marchuk S.I., Zalesskaya I.S., Tretyak A.N., Hvostova I.I., Danilova L.I. Osobennosti genotipa lic, sovershivshih parasuicide [Features of the genotype of individuals who have committed suicide attempts]. Psihiatriya, psihoterapiya i klinicheskaya psihologiya / Psychiatry, Psychotherapy \& Clinical Psychology 2019; 10 (3): 417-427 (in Russ.).

6. Davidovskij S.V. Osobennosti suicidal'nogo povedeniya sredi zhitelej g. Minska [Features of suicidal behavior among residents of Minsk]. Zdravoohranenie / Health Protection (Minsk) 2016; 3: $72-77$ (In Russ.).

7. Dar'in, E.V. Nesuicidal'noe samopovrezhdayushchee povedenie $\mathrm{u}$ podrostkov [Non-suicidal self-injurious behavior in adolescents]. Medicinskij vestnik Yuga Rossi / Medical Journal of the South of Russia 2019; 10 (4): 6-14 (In Russ.).

8. Zinchk M., Avedisova A., Guekht A. Nesuicidal'noe samopovrezhdayushchee povedenie pri psihicheskih rasstrojstvah nepsihoticheskogo urovnya: epidemiologiya, social'nye i klinicheskie faktory [Nonsuiciidal self-injury behavior in non-psychotic disorders: Epidemiology, social and clinical risk factors]. Zhurnal nevrologii i psihiatrii / J. Neurology \& Psychiatry 2019; 24 (3): 108-116. (In Russ.).

https://doi.org/10.17116/jnevro2019119031108

9. Igumnov S.A., Gelda A.P., Gutkevich E.V., Schastnyy E.D. Mediko-social'nye aspekty suicidal'nogo povedeniya podrostkov i molodezhi [Medico-social aspects of suicidal behavior in adolescence and youth]. Scientific editor N.A. Bokhan. Moscow, Minsk, Tomsk: Printing House Integrated Casework Ltd, 2020. 178 p. (in Russ.).

10. Klimenko T., Kozlov A., Igumnov S., Fastovtsov G., Zbarousky K., Iskandarov R. Narkologicheskie rasstrojstva v epohu pandemii COVID-19: analiticheskij obzor [Drug Disorders in the Era of the COVID-19 Pandemic: A Scientific Review] Voennaya medicina / Military Medicine 2021; 1 (58): 94-104. (In Russ.).

11. Popov Yu.V., Pichikov A.A. Suicidal'noe povedenie u podrostkov [Suicidal behavior in adolescents]. Sankt-Peterburg: SpecLit, 2017: 366. [(n Russ.)
12. Andover M. S. Non-suicidal self-injury disorder in a community sample of adults. Psychiatry Res. 2014; (219): 305-310.

https://doi.org/10.1016/j.psychres.2014.06.001

13. Barrocas A.L., Hankin B.L., Young J.L., Abela J.R. Rates of nonsuicidal self- injury in youth: age, sex, and behavioural methods in a community sample. Pediatrics 2012; (130): 39-45. https://doi.org/10.1542/peds.2011-2094

14. Di Clemente R.J, Ponton L.E., Hartley D. Prevalence and correlates of cutting behavior: risk for HIV transmission. J. Am. Acad. Child Adolesc. Psychiatry 1991; (30): 735-739.

https://doi.org/10.1097/00004583-199109000-00006

15. Briere J., Gil E. Self-mutilation in clinical and general population samples: prevalence, correlates, and functions. Am. J. Orthopsychiatry 1998; (68): 609-620. https://doi.org/10.1037/h0080369

16. Bolognini M., Plancherel B., Laget J., Stephan P., Halfon O. Adolescents' self-mutilation - relationship with dependent behaviour. Swiss J. Psychol. 2003; (62): 241-249.

https://doi.org/10.1024/1421-0185.62.4.241

17. Casey B.J., Jones R.M., Hare T.A. The adolescent brain. Ann. N.Y. Acad. Sci. 2008; (1124): 111-126.

https://doi.org/10.1196/annals.1440.010

18. Cheng K.F., Leung P.C. (2007). What happened in China during the 1918 influenza pandemic? Int J Infect Dis. 2007; 11(4): $360-364$. https://doi.org/10.1016/j.ijid.2006.07.009

19. Chen Y.Y, Wu. K.C., Yousuf S., Yip P.S. Suicide in Asia: opportunities and challenges. Epidemiol Rev. 2012; (34): 129-144. https://doi.org/10.1093/epirev/mxr025

20. Crowell S.E, Beauchaine T.P., McCauley E., Smith C.J., Stevens A.L., Sylvers P. Psychological, autonomic, and serotonergic correlates of parasuicide among adolescent girls. Dev. Psychopathol 2005; 17(4):1105-27

https://doi.org/10.1017/S0954579405050522

21. Darche M.A. Psychological factors differentiating self-mutilating and non-self-mutilating adolescent inpatient females. Psychiatr. Hosp. 1990; (21): 31-35.

22. Dwivedi Y. The Neurobiological Basis of Suicide. University Boca Raton (FL): CRC Press/Taylor \& Francis, 2012. 482 p. https://doi.org/10.1201/b12215

23. Fanelli G., Serretti A. The influence of the serotonin transporter gene 5-HTTLPR polymorphism on suicidal behaviors: a meta-analysis. Prog. Neuropsychopharmacol. Biol. Psychiatry 2018; 88: 375-387.

https://doi.org/10.1016/j.pnpbp.2018.08.007

24. Favazza A.R. Bodies under Siege: Self-mutilation and Body Modification in Culture and Psychiatry, 2nd Edn. Baltimore, MD: John Hopkins University Press, 1996.

25. Favazza A.R., Rosenthal R.J. Varieties of pathological selfmutilation. Behav. Neurol. 1990; (3): 77-85.

https://doi.org/10.1155/1990/572716

26. Galynker I., Yaseen Z.S, Cohen A. et al. Prediction of suicidal behavior in high risk psychiatric patients using an assessment of acute suicidal state: the Suicide Crisis Inventory. Depress Anxiety. 2017; (34): 147-158.

https://doi.org/10.1002/da.22559 
27. Glenn C.R., Klonsky E.D. Non-suicidal self-injury disorder: an empirical investigation in adolescent psychiatric patients. J. Clin. Child Adolesc. Psychol. 2013; (42): 496-507. https://doi.org/10.1080/15374416.2013.794699

28. Graff H., Mallin R. The syndrome of the wrist cutter. Am. J. Psychiatry 1967; (124): 74-80. https://doi.org/10.1176/ajp.124.1.36

29. Gratz K.L., Dixon-Gordon K.L., Chapman A.L., Tull M.T. Diagnosis and characterization of DSM-5 non-suicidal selfinjury disorder using the clinician administered non-suicidal self-injury disorder index. Assessment 2015; (22): 527-539. https://doi.org/10.1177/1073191114565878

30. Gratz K.L., Conrad S.D., Roemer L. Risk factors for deliberate self-harm among college students. Am. J. Orthopsychiatry 2002; (1): 128-140.

https://doi.org/10.1037/0002-9432.72.1.128

31. Gratz K.L. Risk factors for deliberate self-harm among female college students: the role and interaction of childhood maltreatment, emotional inexpressivity, and affect intensity/reactivity. Am. J. Orthopsychiatry 2006; (76): 238-250.

https://doi.org/10.1037/0002-9432.76.2.238

32. Gunnell D., Appleby L., Arensman E., Hawton K., John A., Kapur N. et al. Suicide risk and prevention during the COVID-19 pandemic. Lancet Psychiatry 2020. https://doi.org/10.1016/S2215-0366(20)30171-1

33. Harter S., Stocker C., Robinson N.S. The perceived directionality of the link between approval and selfworth: the liabilities of a looking glass self-orientation among young adolescents. J. Res. Adolesc. 1996; (6): 285-308.

34. Hilt L., Nock M., Lloyd-Richardson E., Prinstein M. Longitudinal study of nonsuicidal self-injury among young adolescents: Rates, correlates, and preliminary test of an interpersonal model. The Journal of Early Adolescence 2008; 28 (3): 455-469. https://doi.org/10.1177/0272431608316604

35. Holmes E.A., O'Connor R.C., Perry V.H., Tracey I., Wessely S., Arseneault L. et al. Multidisciplinary research priorities for the COVID-19 pandemic: a call for action for mental health science. Lancet Psychiatry 2020; (7): 547-60. https://doi.org/10.1016/S2215-0366(20)30168-1

36. Iannaccone M., Cella S., Manzi S.A., Visconti L., Manzi F., Cotrufo P. My body and me: self-injurious behaviors and body modifications in eating disorders-preliminary results. Eat. Disord. 2013; (21): 130-139.

https://doi.org/10.1080/10640266.2013.761087

37. In-Albon T., RufC., Schmid M. Proposed diagnostic criteria for the DSM-5 of non-suicidal self-injury in female adolescents: diagnostic and clinical correlates. Psychiatry J. 2013; (2013): 159-208.

https://doi.org/10.1155/2013/159208

38. Iob E., Steptoe A., Fancourt D. Abuse, self-harm and suicidal ideation in the UK during the COVID-19 pandemic. The British Journal of Psychiatry 2020; 217(4): 543-546. https://doi.org/10.1192/bjp.2020.130

39. Janis I.B., Nock M.K. Are self-injurers impulsive? Results from two behavioral laboratory studies. Psychiatry Research 2009; (169): 261-267. https://doi.org/10.1016/j.psychres.2008.06.041

40. Johnson N.P., Mueller J. Updating the accounts: Global mortality of the 1918-1920 "Spanish" influenza pandemic. Bulletin of the History of Medicine 2002; 76 (1): 105-115.

https://doi.org/10.1353/bhm.2002.0022

41. Joiner T.E., Simpson S., Rogers M.L., Stanley I.H., Galynker I. Whether Called Acute Suicidal Affective Disturbance or Suicide Crisis Syndrome, a Suicide-specific Diagnosis Would Enhance Clinical Care, Increase Patient Safety, and Mitigate Clinician Liability. Journal of Psychiatric Practice 2018; (24) 4: 274-278. https://doi.org/10.1097/PRA.0000000000000315

42. Kaess M., Hille M., Parzer P., Maser-Gluth C., Resch F., Brunner R. Alterations in the neuroendocrinological stress response to acute psychosocial stress in adolescents engaging in nonsuicidal self-njury. Psychoneuroendocrinology 2012; (37): 157-161.

https://doi.org/10.1016/j.psyneuen.2011.05.009

43. Kaess M., Parzer P., Mattern M., Plener P.L., Bifulco A., Resch F. et al. Adverse childhood experiences and their impact on frequency, severity, and the individual function of nonsuicidal self-injury in youth. Psychiatry Res 2013; (206): 265-272. https://doi.org/10.1016/j.psychres.2012.10.012

44. Kahan J., Pattison E.M. Proposal for a distinctive diagnosis: the deliberate self-harm syndrome (DSH). Suicide Life Threat. Behav 1984; (14): 17-35. https://doi.org/10.1111/j.1943-278X.1984.tb00334.x

45. Kraus A., Valerius G., Seifritz E., Ruf M., Bremner J. D., Bohus M. et al. Script-driven imagery of self-injurious behaviour in patients with borderline personality disorder: a pilot FMRI study. Acta Psychiatrica Scandinavica 2010; (121): 41-51. https://doi.org/10.1111/j.1600-0447.2009.01417.x

46. Klonsky E.D. Non-suicidal self-injury in United States adults: prevalence, sociodemographics, topography and functions. Psychol. Med 2011; (41): 1981-1986. https://doi.org/10.1017/S0033291710002497

47. Klonsky E.D., Oltmanns T.F., Turkheimer E. Deliberate selfharm in a nonclinical population: prevalence and psychological correlates. Am. J. Psychiatry 2003; (160): 1501-1508. https://doi.org/10.1176/appi.ajp.160.8.1501

48. Laye-Gindhu A., Schonert-Reichl K.A. Nonsuicidal self-harm among community adolescents: understanding the whats and whys of self-harm. J. Youth Adolesc 2005; (34): 447-457. https://doi.org/10.1007/s10964-005-7262-z

49. Ludäscher P., Greffrath W., Schmahl C., Kleindienst N., Kraus A., Baumgärtner U. et al. A cross-sectional investigation of discontinuation of self-injury and normalizing pain perception in patients with borderline personality disorder. Acta Psychiatrica Scandinavica 2009; (120): 62-70. https://doi.org/10.1111/j.1600-0447.2008.01335.x

50. Mahase E. Covid-19: Where are we on immunity and vaccines? BMJ 2020; 5(370): m3096. https://doi.org/10.1136/bmj.m3096

51. Miller A.B., Prinstein M.J. Adolescent suicide as a failure of acute stress-reponse systems. Annual Reviera of Clinical Psychology 2019: (02):12. 
52. Moran P., Coffey C., Romaniuk H., Degenhardt L., Borschmann R., Patton G.C. Substance use in adulthood following adolescent self-harm: a population-based cohort study. Acta Psychiatrica Scandinavica 2015; 131 (1): 61-68.

https://doi.org/10.1111/acps.12306

53. Moran P., Coffey C., Romaniuk H., Olsson C., Borschmann R., Carlin J. B., \& Patton G. C. The natural history of self-harm from adolescence to young adulthood: A population based cohort study. The Lancet 2011; (379): 236 - 243. https:/doi.org/10.1016/S0140-6736(11)61141-0

54. Muehlenkamp J.J., Claes L., Havertape L., Plener P.L. International prevalence of adolescent non-suicidal self-injury and deliberate self-harm. Child Adolesc. Psychiatry Ment. Health 2012; (6): 1-9.

https://doi.org/10.1186/1753-2000-6-10

55. Muehlenkamp J.J., Gutierrez P.M. Risk for suicide attempts among adolescents who engage in non-suicidal self-injury. Arch Suicide Res 2007; (11): 69-82.

https://doi.org/10.1080/13811110600992902

56. Muehlenkamp J.J. Self-injurious behavior as a separate clinical syndrome. Am. J. Orthopsychiatry 2005; (75): 324-333. https://doi.org/10.1037/0002-9432.75.2.324

57. Nixon M.K., Cloutier P.F., Aggarwal S. Affect regulation and addictive aspects of repetitive self- injury in hospitalized adolescents. Journal of the American Academy of Child and Adolescent Psychiatry 2002; (41): 1333-1341.

https://doi.org/10.1097/00004583-200211000-00015

58. Nock M.K., Joiner T.E., Gordon K.H., Lloyd-Richardson E., Prinstein M.J. Nonsuicidal self-injury among adolescents: diagnostic correlates and relation to suicide attempts. Psychiatry Res 2006; (144): 65-72.

https://doi.org/10.1016/j.psychres.2006.05.010

59. Nock, M.K., Prinstein M.J. A functional approach to the assessment of self-mutilative behavior. J. Clin. Consult. Psychol. 2004; (72): 885-890.

https://doi.org/10.1037/0022-006X.72.5.885

60. Nock M.K., Prinstein M.J., Sterba S.K. Revealing the form and function of self-injurious thoughts and behaviors: A real-time ecological assessment study among adolescents and young adults. Journal of Abnormal Psychology 2009; 118(4): 816. https://doi.org/10.1037/a0016948

61. Nock M.K. Self-injury. Annu. Rev. Clin. Psychol 2010; (6): 339-363.

https://doi.org/10.1146/annurev.clinpsy.121208.131258

62. Oquendo M.A, Baca-Garcia E. Suicidal behavior disorder as a diagnostic entity in the DSM-5 classification system: advantages outweigh limitations. World Psychiatry 2014; (13): 128-130.

https://doi.org/10.1002/wps.20116

63. Pao P. The syndrome of delicate self-cutting. Br. J. Med. Psychol. 1969; (42): 213-221.

https://doi.org/10.1111/j.2044-8341.1969.tb02071.x

64. Plener P. L., Libal G., Keller F., Fegert J. M., Muehlenkamp, J. J. An international comparison of non-suicidal self-injury (NSSI) and suicide attempts: Germany and the USA. Psychol. Med. 2009; (39): 1549-1558.
https://doi.org/10.1017/S0033291708005114

65. Rosenthal R., Rinzler C., Wallsch R., Klausner E. Wrist-cutting syndrome: the meaning of a gesture. Am. J. Psychiatry 1972; (128): 1363-1368. https://doi.org/10.1176/ajp.128.11.1363

66. Regier M.A., Narrow W.E., Clarke D.E., Kraemer H.C., Kuramoto S.J., Kuhl E.A. et al. DSM-5 field trials in the United States and Canada, part II: test-retest reliability of selected categorical diagnoses. Am. J. Psychiatry 2013; (170): 59-70. https://doi.org/10.1176/appi.ajp.2012.12070999

67. Reger M.A., Stanley I.H., Joiner T.E. Suicide Mortality and Coronavirus Disease 2019-A Perfect Storm? JAMA Psychiatry 2020; 77(11): 1093-1094.

https://doi.org/10.1001/jamapsychiatry.2020.1060

68. Rogers M.L, Galynker I., Yaseen Z., et al. An overview and comparison of two proposed suicide-specific diagnoses: Acute Suicidal Affective Disturbance (ASAD) and Suicide Crisis Syndrome (SCS). Psychiatr Ann. 2017; (47): 416-420. https://doi.org/10.3928/00485713-20170630-01

69. Schmahl C., Bohus M., Esposito F., Treede R.D., Di Salle F., Greffrath W. et al. Neural correlates of antinociception in borderline personality disorder. Archives of General Psychiatry 2006; (63): 659-67.

https://doi.org/10.1001/archpsyc.63.6.659

70. Selby E.A., Bender T.W., Gordon K.H., Nock M.K., Joiner T.E. Non-suicidal selfinjury (NSSI) disorder: a preliminary study. Personal. Disord. 2012; (3): 167-175.

https://doi.org/10.1037/a0024405

71. Shaffer D., Jacobson C. Proposal to the DSM-V Childhood Disorder and Mood Disorder Work Groups to Include NonSuicidal Self-Injury (NSSI) as a DSM-V disorder. Washington, DC: American Psychiatric Association, 2009.

72. Somerville L.H., Jones R.M., Ruberry E.J., Dyke J.P., Glover G., Casey B.J. The medial prefrontal cortex and the emergence of self-conscious emotion in adolescence. Psychol. Sci. 2013; 24 (8): 1554-1562. https://doi.org/10.1177/0956797613475633

73. Stanley B., Sher L., Wilson S., Ekman R., Huang Y. \& Mann J. Non-suicidal self-injurious behaviour, endogenous opioids and monoamine neurotransmitters. Journal of Affective Disorders 2010; (124): 134-140. https://doi.org/10.1016/j.jad.2009.10.028

74. Stroud L.R., Foster E., Papandonatos G.D., Handwerger K., Granger D.A. [et al.] Stress response and the adolescent transition: performance versus peer rejection stressors. Dev. Psychopathol. 2009; 21 (1): 47-68. https://doi.org/10.1017/S0954579409000042

75. The Oxford handbook of suicide and self-injury / edited by Matthew K. Nock. New York: Oxford University Press; 2017: 516.

76. Tiefenbacher S., Novak M.A., Lutz C.K., Meyer J.S. The physiology and neurochemistry of self-injurious behaviour: A nonhuman primate model. Frontiers in Bioscience 2005; (10): 1-11. https://doi.org/10.2741/1500

77. Turner B.J., Dixon-Gordon K.L., Austin S.B., Rodriguez M.A., Rosenthal M.Z., Chapman A.L. Non-suicidal self-injury with 
and without borderline personality disorder: differences in self-injury and diagnostic comorbidity. Psychiatry Res. 2015; (230): 28-35.

https://doi.org/10.1016/j.psychres.2015.07.058

78. Van Heeringen K. The Neuroscience of Suicidal Behavior. Hardcover, Cambridge University Press, 2018. 286 p. https://doi.org/10.1017/9781316563205

79. Washburn, J. J., Potthoff, L. M., Juzwin, K. R., and Styer, D. M. Assessing DSM-5 non-suicidal self-injury disorder in a clinical sample. Psychol. Assess. 2015; (27): 31-41. https://doi.org/10.1037/pas0000021

80. Whitlock J., Eckenrode J., Silverman D. Whitlock J. Selfinjurious behaviors in a college population. Pediatrics 2006; (117): 1939-1948. https://doi.org/10.1542/peds.2005-2543

81. Wilkinson P., Goodyer I. Non-suicidal self-injury. Eur. Child Adolesc. Psychiatry 2011; (20): 103-108.

https://doi.org/10.1007/s00787-010-0156-y

82. Word Preventing suicide: A global imperative. Geneva: Word Health Organization; 2014. Available at http://www.who.int/ mental_health/suicide-prevention/

83. Zetterqvist M., Lundh L.G., Dahlström Ö., Svedin C.G. Prevalence and function of non-suicidal self-injury (NSSI) in a community sample of adolescents, using suggested DSM-5 criteria for a potential NSSI disorder. J. Abnorm. Child Psychol. 2013; (41): 759-773.

https://doi.org/10.1007/s10802-013-9712-5

\section{SAVE ŽALOJANČIO ELGESIO SAMPRATA IR CHARAKTERISTIKOS}

\section{S. Igumnov, S. Davidovsky, R. Iskandarov, O. Iskandarova}

Raktažodžiai: savižudiškas ir save žalojantis elgesys, mintys apie savižudybę, Tarptautinė ligų klasifikacija (10 leidimas), ribinis asmenybės sutrikimas, alkoholis, psichiką veikiančios medžiagos, COVID-19 pandemija.
Santrauka

Šiuo metu yra nustatyti keli biologiniai savižudiško ir save žalojančio elgesio rizikos veiksniai. Skirtumai, susiję su pagrindinių neuromediatorių sistemų pokyčiais (serotoninergine, poliamino streso atsako, glutamatergine ir GABAergine sistemomis), uždegiminiu atsaku, astroglijos disfunkcija, neuronų plastiškumo faktoriumi, patvirtina poreikị diferencijuoti motyvuotus įvykdyti savižudybę nuo linkusių ị save žalojantị elgesị, kai nesiekiama nusižudyti.

Nesavižudiškas save žalojantis elgesys (savęs žalojimo mintys ir elgesys arba savižudiškas savęs sužalojimas - NSŽE) apibrèžiamas kaip pakartotinis, apgalvotas, tiesioginis kūno pažeidimas nesant savižudiškų tikslų, kuris nėra socialiai priimtinas. Integruotas teorinis NSŽE išsivystymo ir palaikymo modelis rodo, kad tokio tipo elgesys veikia kaip emocinès patirties ir socialinès sąveikos reguliavimo metodas, atsiradus stresiniam poveikiui. NSŽE šiuo metu yra įtrauktas į DSM-5 3 skyrių (Psichikos sutrikimų diagnostinis ir statistinis vadovas, 5 leidimas) ir yra nurodytas kaip būsena, rekomenduojama tolesniems tyrimams. Amerikos Psichikos sutrikimų diagnostikos ir statistikos vadovas, 4 leidimas (DSM-IVTR) ir Tarptautinė ligų klasifikacija, 10 leidimas, peržiūra (TLK10) koduoja NSSŽE kaip ribinio asmenybès sutrikimo požymį.

Naujausi tyrimai parodè, kad 59,6\% asmenų, sergančių NSŽE, turi piktnaudžiavimo narkotikais tendenciją.

Nerimaujama, kad dèl COVID-19 pandemijos ir po jos gali padidèti savižudybių ir savižudiško elgesio rodikliai.

Adresas susirašinėti: sigumnov67@gmail.com

Gauta 2021-07-19 